\title{
THE USE OF WATER PLANTS IN BIOMONITORING AND PHYTOREMEDIATION OF WATERS POLLUTED WITH HEAVY METALS
}

\author{
WYKORZYSTANIE ROŚLIN WODNYCH W BIOMONITORINGU \\ I FITOREMEDIACJI WÓD ZANIECZYSZCZONYCH METALAMI CIĘŻKIMI
}

\begin{abstract}
The publication is a synthetic review of many years of research on the possibility of using water plants (macrophytes) to assess pollution of surface waters and the possibility of using the biomass in phytoremediation processes. The results of the research of kinetics and equilibria of heavy metals sorption and desorption conditions were presented in order to repeatedly use the biomass, as well as the research on the influence of abiotic factors on sorption processes. Defence mechanisms of macrophytes, which enable them to vegetate in considerably polluted waters, have been discussed. The results presented herein and carried out in many countries demonstrate that macrophytes can be successfully used in the biomonitoring of water environments and phytoremediation of waters and sewage; however, validation of these procedures requires more detailed research of the mechanisms, which accompany them.
\end{abstract}

Keywords: water plants, heavy metals, sorption, biomonitoring, phytoremediation

\section{Introduction}

The concept of a "water plant" is a matter of convention. It is difficult to build a coherent definition of these groups of organisms, due to the connections of both higher and lower water plants with various transitory forms of land plants. One of the definitions describes water plants (hydrophytes) as the organisms, which by way of natural selection adapted to a water environment and are inseparably connected with it. Another term defines water plants, also referred to as macrophytes, as the plants belonging to different systematic groups, excluding single-cell and colonial algae. Macrophytes are often regarded as the group of plants including vascular plants, water moss and algae generating macroscopic thallus. Macrophytes are quite a differentiated group of plants from a morphological point of view. In Poland, the group includes all chara (Charophyta), some mosses (Bryophyta), a few ferns (Pteridophyta) and a small group of spermatophytes (Spermatophyta) [1-5].

\footnotetext{
${ }^{1}$ Chair of Biotechnology and Molecular Biology, Opole University, ul. kard. B. Kominka 6, 45-032 Opole, Poland, phone +48 7740160 42, fax +48 7740160 50, email: aklos@uni.opole.pl

*Corresponding author: kremspawel@gmail.com
} 
Water plants have many common features, which result from the fact that they are perennial plants, which lose their assimilation organs in winter [1]. They inhabit the littoral zone of rivers and water reservoirs, from the banks to the light penetration zone, which indicates that macrophytes live in differentiated habitats $[6,7]$.

The research of the accumulative properties of water plants have been carried out for many years in order to use them in biomonitoring and phytoremediation of waters contaminated by heavy metals. The research focuses on, among others, sorption mechanisms, the factors influencing the process kinetics and equilibrium as well as mutual relations between concentrations of pollution accumulated in their structure and habitat. Macrophytes' resistance to pollution and the possibility of their repeated use in water and sewage phytoremediation processes have been tested.

The most frequent immersed and floating types and species of water plants in Poland tested for the possibility of using them in biomonitoring of water ecosystems and water and sewage phytoremediation are Elodea canadensis L., Ceratophyllum demersum L., Myriophyllum spitacum L., Potamogetonaceae and Lemna minor L. [8-12].

The objective of the research was to systematise the obtained results and conclusions regarding sorption properties of various types of water plants, in particular the immersed and floating plants, published in science magazines accessible in Science Direct base. The results of research regarding the use of macrophytes for biomonitoring and phytoremediation of waters were presented.

\section{Biosorption and bioaccumulation of heavy metals by macrophytes}

In order to assess sorption qualities of macrophytes, research has been in progress on sorption kinetics and equilibrium parameters. The assessment includes also the possibility of desorption of the accumulated heavy metals from plants biomass in order to reuse it in phytoremediation processes.

The immersed and floating water plants can absorb heavy metals from bottom sediments via their root systems, if they have one, or via their whole surface directly from water. It was confirmed that concentrations of the analytes accumulated in water plants are correlated with their concentrations in water and/or bottom sediments [13].

It is assumed that the process of sorption of metals via the surface of water plants by ions exchange $[14,15]$; however, it was also noticed that the sorption mechanism can have different characteristics, which is confirmed by low energy of the sorption process activation and, in certain cases, fast and easy desorption processes [16, 17].

The process of ions exchange, as the main mechanism of cations sorption, is indicated by the studies carried out with Potamogeton natans. It was confirmed that, among others, this macrophyte sorbs hydrogen cations at low $\mathrm{pH}$ values of the solution and then desorbs with the increasing $\mathrm{pH}$ of the solution, which it was in contact with [18]. Similar conclusions were made on the basis of the research results, which show that heavy metals cations sorption is simultaneous with desorption of cations naturally bound in macrophytes: $\mathrm{H}^{+}, \mathrm{Na}^{+}, \mathrm{K}^{+}, \mathrm{Ca}^{2+}$ and $\mathrm{Mg}^{2+}[19,20]$.

Veglio and Beolchini declared that there are many ways of metals absorption by plant cells. They divided biosorption processes into surface sorption as well as extra- and intracellular accumulation [21]. Another division differentiates biosorption as a fast and reversible process, based on physical and chemical binding of metals cations (complexing 
and chelation, ions exchange, microprecipitation and adsorption) and bioaccumulation, as a slow and irreversible process, which takes place in living organisms only and which mainly influences a cell's metabolic activity [22-24].

Mainly the model of the pseudo-second order reaction [23, 25-30] and, less frequently, the model of the pseudo-first order (the Lagergren model) [19] is used to describe sorption kinetics. The studies of kinetics aim at establishing the reaction speed constant. This parameter assists in being able to assess the sorption efficiency in time, also in dynamic equilibrium status.

The research results show that the time needed to achieve equilibrium depends on the plant type but also on the type of sorbed cations. The example is the study of nickel and chromium sorption in Elodea canadensis. It was confirmed that, depending on the initial concentration of the solution, E. canadensis accumulates in the same time from 25 to 40 times more $\mathrm{Ni}$ than $\mathrm{Cr}$. For example, after 24-hour sorption, Ni content in the plant biomass amounted to $0.037 \mathrm{mmol} / \mathrm{g} \mathrm{d.m.,} \mathrm{and} \mathrm{Cr} 0.0016 \mathrm{mmol} / \mathrm{g} \mathrm{d.m}$. (d.m. - dry mass) [31].

One of the examples of the studies of surface sorption kinetics is the studies of copper, zinc and lead cations in macrophytes: Myriophyllum spicatum and Ceratophyllum demersum. The results of studies of the sorption from solutions of these metals with volume of $250 \mathrm{~cm}^{3}$ and initial concentrations of $10 \mathrm{mg} / \mathrm{dm}^{3}$ show that the time required to achieve dynamic equilibrium is approximately 20 minutes [25]. This was confirmed by other tests on the same plant species [23, 26, 29]; however, it is emphasised that the equilibrium status during sorption of copper in Myriophyllum spicatum is achieved after 35 minutes [30]. Other studies of lead sorption with the same macrophyte show that after 10 minutes, $66 \%$ of lead cations present in initial solution were sorbed, whereas in dynamic equilibrium achieved after 20 minutes, $85 \%$ of Pb cations were sorbed [28]. Studies of mercury sorption kinetics in Potamogeton natans show that after 30 minutes approximately $90 \% \mathrm{Hg}$ was sorbed from solutions [18].

Studies of sorption kinetics and efficiency relate also to the above-mentioned bioaccumulation - a slow process lasting many days.

The example is cadmium bioaccumulation studies in the plants Myriophyllum. Sorption was carried out from the solutions with concentrations from 0.018 to $0.14 \mathrm{mmol} / \mathrm{dm}^{3}$. After 96 hours, from 81 to $95 \%$ of Cd cations were sorbed, depending on the plant type and initial concentration of cadmium in the solution [32]. Macrophyte Ceratophyllum demersum kept in selene solution with concentration of $0.13 \mathrm{mmol} / \mathrm{dm}^{3}$, after 31 days sorbed $0.0062 \pm 0.0011 \mathrm{mmol} / \mathrm{g} \mathrm{d}$.m., whereas Myriophyllum spicatum after 13 days sorbed $0.0027 \pm 0.0001 \mathrm{mmol} / \mathrm{g} \mathrm{d.m}$. of the analyte [33]. In other studies, Ceratophyllum demersum, after $24 \mathrm{~h}$ in arsenic solution with initial concentration of $0.04 \mathrm{mmol} / \mathrm{dm}^{3}$ sorbed $0.003 \mathrm{mmol} / \mathrm{g} \mathrm{d}$.m. of this element, and after 48 hours $0.004 \mathrm{mmol} / \mathrm{g} \mathrm{d.m}$. [34]. After 7 days, from the solution with initial lead concentration of lead of $0.1 \mathrm{mmol} / \mathrm{dm}^{3}$ this macrophyte accumulated $0.008 \mathrm{mmol} / \mathrm{g} \mathrm{d} . \mathrm{m}$. $\mathrm{Pb}(95.8 \%)$; however, most of the lead was accumulated already after day 1: $0.0059 \mathrm{mmol} / \mathrm{g} \mathrm{d.m.,} \mathrm{ie} 70 \%$ of the available lead cations [35].

Studies of heavy metals sorption efficiency by Potamogeton pectinatus and Potamogeton malaianus showed that they accumulate on average $92 \% \mathrm{Cd}, 79 \% \mathrm{~Pb}, 86 \%$ $\mathrm{Mn}, 70 \% \mathrm{Cu}$ and $67 \% \mathrm{Zn}$, present in the initial solution [36]. A comparison of sorption properties Elodea canadensis and Salvinia sp. was carried out [37] and sorption 
characteristics of Lemna minor, in which from the solution with initial concentration of $10 \mathrm{mg} / \mathrm{dm}^{3}$ the sorbed volumes were $98.83 \% \mathrm{~Pb}, 94.07 \% \mathrm{Cd}, 72.78 \% \mathrm{Cu}, 69.03 \% \mathrm{Ni}$ and $63.42 \% \mathrm{Zn}$. It was confirmed that the efficiency of sorption of most metals was greater in the solutions with the initial concentrations of $10 \mathrm{mg} / \mathrm{dm}^{3}$ in comparison with the solutions with twice as large concentrations, which probably results from filling the active centres by the sorbed metals [19].

The presented research results show that the equilibria resulting from surface sorption, the main mechanism of which is the ions exchange, stabilise after approximately 30 minutes. In the case of bioaccumulation in extra- and intracellular structures, studies of sorption processes can even last several dozen days [38].

Table 1

Equilibrium parameters of the selected types of water plants: $c_{\max }$ - sorption capacity, $t$ - time needed to achieve equilibrium, $\mathrm{pH}$ of the solution in equilibrium

\begin{tabular}{|c|c|c|c|c|c|c|}
\hline \multirow{2}{*}{ Aquatic plants } & \multirow{2}{*}{ Heavy metal } & \multicolumn{2}{|c|}{$c_{\max }$} & \multirow{2}{*}{$t$ [min] } & \multirow{2}{*}{ pH } & \multirow{2}{*}{ References } \\
\hline & & [mg/g d.m.] & [mmol/g d.m.] & & & \\
\hline \multirow{15}{*}{$\begin{array}{l}\text { Myriophyllum } \\
\text { spicatum }\end{array}$} & $\mathrm{Cu}$ & 10.37 & 0.163 & \multirow{3}{*}{120} & \multirow{3}{*}{$5.0-6.0$} & \multirow{3}{*}{ [23] } \\
\hline & $\mathrm{Zn}$ & 15.59 & 0.238 & & & \\
\hline & $\mathrm{Pb}$ & 46.49 & 0.224 & & & \\
\hline & $\mathrm{Cu}$ & 6.20 & 0.098 & \multirow{3}{*}{120} & \multirow{3}{*}{$5.0-6.0$} & \multirow{3}{*}[25]{} \\
\hline & $\mathrm{Zn}$ & 14.00 & 0.214 & & & \\
\hline & $\mathrm{Pb}$ & 45.00 & 0.217 & & & \\
\hline & $\mathrm{Pb}$ & 41.14 & 0.199 & 120 & 5.0 & {$[28]$} \\
\hline & $\mathrm{Cu}$ & 12.07 & 0.190 & - & - & [29] \\
\hline & $\mathrm{Cu}$ & 10.80 & 0.170 & 120 & $5.0-6.0$ & [30] \\
\hline & $\mathrm{Co}$ & 2.30 & 0.039 & \multirow{3}{*}{120} & \multirow{3}{*}{8.0} & \multirow{3}{*}{ [39] } \\
\hline & $\mathrm{Ni}$ & 3.00 & 0.051 & & & \\
\hline & $\mathrm{Zn}$ & 6.80 & 0.104 & & & \\
\hline & $\mathrm{Cu}$ & 12.90 & 0.203 & \multirow{3}{*}{60} & \multirow{3}{*}{-} & \multirow{3}{*}{ [40] } \\
\hline & $\mathrm{Zn}$ & 13.50 & 0.206 & & & \\
\hline & $\mathrm{Pb}$ & 55.60 & 0.268 & & & \\
\hline \multirow{2}{*}{$\begin{array}{l}\text { Myriophyllum } \\
\text { alterniflorum }\end{array}$} & $\mathrm{Cu}$ & 13.90 & 0.219 & \multirow{2}{*}{120} & \multirow{2}{*}{5.0} & \multirow{2}{*}{ [27] } \\
\hline & $\mathrm{Cd}$ & 11.10 & 0.099 & & & \\
\hline \multirow{6}{*}{$\begin{array}{l}\text { Ceratophyllum } \\
\text { demersum }\end{array}$} & $\mathrm{Cu}$ & 6.17 & 0.097 & \multirow{3}{*}{120} & \multirow{3}{*}{$5.0-6.0$} & \multirow{3}{*}{ [25] } \\
\hline & $\mathrm{Zn}$ & 13.98 & 0.214 & & & \\
\hline & $\mathrm{Pb}$ & 44.80 & 0.216 & & & \\
\hline & $\mathrm{Cu}$ & 6.17 & 0.097 & \multirow{3}{*}{120} & \multirow{3}{*}{$5.0-6.0$} & \multirow{3}{*}[26]{} \\
\hline & $\mathrm{Zn}$ & 13.90 & 0.213 & & & \\
\hline & $\mathrm{Pb}$ & 44.80 & 0.216 & & & \\
\hline \multirow{3}{*}{$\begin{array}{l}\text { Potamogeton } \\
\quad \text { lucens }\end{array}$} & $\mathrm{Cu}$ & 40.80 & 0.642 & & & \\
\hline & $\mathrm{Zn}$ & 32.40 & 0.495 & - & - & {$[15]$} \\
\hline & $\mathrm{Pb}$ & 141.00 & 0.681 & & & \\
\hline $\begin{array}{c}\text { Potamogeton } \\
\text { natans }\end{array}$ & $\mathrm{Hg}$ & 180.00 & 0.897 & 180 & 7.2 & [18] \\
\hline Spirogyra sp. & $\mathrm{Cu}$ & 137 & 2.16 & 40 & 5.0 & [41] \\
\hline
\end{tabular}

The Langmuir isotherm model is mainly used to describe dynamic equilibrium [23, 25-27, 29]. It assumes the existence of a definite number of active locations, in which sorption of only one chemical substance is possible. The maximum sorption capacity is equal to filling all active locations. The authors also point out good correlations between the experimental data and calculations from the model [23, 25, 28, 29]. The equilibrium status 
is also described by other isotherm models, among others, Freundlich isotherm [38] and Spis isotherm (generalised Freundlich isotherm) [28].

The results of laboratory tests of sorption capacity of different macrophyte types, defined on the basis of Langmuir isotherm, are presented in Table 1. For comparison, the table includes the sorption capacity of Spirogyra sp. referring to copper.

The presented values of sorption capacities in $\mathrm{mmol} / \mathrm{g} \mathrm{d} . \mathrm{m}$. show differences resulting from physical and chemical properties of the sorbed cations. Most of the data presented in the Table show that, after conversion to mol, sorption is most difficult with regard to copper and similarly to zinc and lead cations. These results also show considerable differences in assessment of sorption capacity of the same plant, with reference to one metal. For example, the capacity of Myriophyllum spicatum with regard to copper cations was assessed at $0.098 \mathrm{mmol} / \mathrm{g} \mathrm{d}$.m. [25] and at $0.203 \mathrm{mmol} / \mathrm{g} \mathrm{d} . \mathrm{m}$. [40]. The problem is that authors rarely provide uncertainty of the sorption capacity determination. Tests of copper sorption by Spirogyra sp., within the small initial metal concentrations in solution of $10^{-3}-10^{-2} \mathrm{mmol} / \mathrm{dm}^{3}$, showed that the standard error in sorption capacity determination, depending on the experiment conditions, may amount even to $10^{4} \%$ [42].

There are also differences regarding sorption capacity of immersed and floating plants. The data included in Table 2 show that the best sorption characteristics for $\mathrm{Cu}, \mathrm{Zn}$ and $\mathrm{Pb}$ is the floating leaves plant - Potamogeton lucens. However, numerous other studies emphasise the reverse effect. The comparison of sorption characteristics of several types of macrophytes, with reference to accumulation of $\mathrm{Ni}, \mathrm{Cu}$ and $\mathrm{Cd}$ shows that immersed plants have superior sorption characteristics. Among these plants, Ceratophyllum demersum presented the best sorption characteristics. In experimental conditions, it accumulated $0.0030 \mathrm{mmol} / \mathrm{g} \mathrm{d} . \mathrm{m}$. of Ni, $0.0041 \mathrm{mmol} / \mathrm{g} \mathrm{d} . \mathrm{m}$. of $\mathrm{Cu}$ and $0.00071 \mathrm{mmol} / \mathrm{g} \mathrm{d} . \mathrm{m}$. of Cd. In the same conditions, macrophyte Potamogeton natans with floating leaves accumulated $0.0012 \mathrm{mmol} \mathrm{Ni} / \mathrm{g}$ d.m., $0.0024 \mathrm{mmol} \mathrm{Cu} / \mathrm{g} \mathrm{d.m}$. and $0.00037 \mathrm{mmol} \mathrm{Cd} / \mathrm{g} \mathrm{d} . \mathrm{m}$. [43]. Similar correlations are confirmed by other experiments [43-46]. It is supposed that better sorption characteristics of immersed plants are related to the specific structure of these macrophytes. Their leaves have underdeveloped skin (sometimes none) and lamina, which support a fast exchange of matter with the environment [43].

The presented results of research show, in some cases, considerable differences, which may result from different experiment conditions and a lack of recognition of abiotic and biotic factors, which influence sorption processes.

\section{The influence of abiotic and biotic factors on sorption characteristics of macrophytes}

Accumulation of heavy metals by water plants in natural conditions is influenced by a number of abiotic factors, among others $\mathrm{pH}$, presence of other cations in the waters of the reservoir, temperature, intensity of photosynthetic light and the exposure period, as well as biotic factors, among others, specific features (eg hyperaccumulation capacity and resistance to high concentration of pollution), metal storage and detoxification forms by a plant as well as interaction with other compounds present in a cell [47]. 


\section{The influence of abiotic factors on sorption characteristics of macrophytes}

The $\mathrm{pH}$ of solution is one of the most frequently tested parameters. Hydrogen cations influence solubility of heavy metal compounds; they locate themselves in active centres and influence the ionisation degree of the sorbate during the process. The tests carried out with the use of Myriophyllum spicatum showed that the maximum efficiency of lead cations sorption $(76 \%)$ was achieved at $\mathrm{pH}=5$. Efficiency of $\mathrm{Pb}$ cations sorption at $\mathrm{pH} 2.0$ was only $37 \%$. It was noticed that the very competitive hydrogen cations sorption causes reduction of lead cations sorption [28]. Similar results were obtained when analysis sorption processes of $\mathrm{Se}(\mathrm{VI})$ by Lemna minor within $\mathrm{pH}$ changes range from 2.0 to 8.0. The maximum sorption efficiency is achieved at a solution $\mathrm{pH}$ of 6 [48].

General salinity of a solution has a similar influence on heavy metals sorption. The research carried out with Elodea canadensis and Potamogeton natans showed that with lower salinity, sorption efficiency of $\mathrm{Cu}, \mathrm{Zn}$ and $\mathrm{Cd}$ increases in these macrophytes. The research also showed that temperature influences sorption of metals by macrophytes. It was confirmed that with the increase of temperature within the range from 278 to $293 \mathrm{~K}$, sorption efficiency increases. It is supposed that temperature influences the change of cell membrane lipids composition, which may support metals sorption [49].

\section{Macrophytes resistance and reactions to the presence of heavy metals in their environment}

Heavy metals, among others $\mathrm{Fe}, \mathrm{Mn}, \mathrm{Cu}, \mathrm{Zn}$, Mo and $\mathrm{Co}$, in physiological quantities perform important functions in living organisms; they make up metal-organic compounds, eg metalloproteins and are necessary to maintain the appropriate structure and operation of enzymes. However, they are toxic in greater concentrations. They cause, among others, damage to root cells and limit their growth, change permeability of cell membranes and slow down the transport of electrons in photosynthesis process $[50,51]$.

Water plants, which live in the environment with a high concentration of heavy metals, developed effective defence systems including, among others, a mechanism to avoid metal ions, stopping metals in the cell membrane, eg by organic acids and amino acids, by the increase of glutathione biosynthesis, production and activation of various antioxidant particles and enzymes [35].

Elodea canadensis is the example of a macrophyte, which was many times analysed for anatomical, morphological and physiological changes, caused by the influence of heavy metals. It was found, among others, that Elodea canadensis has a large tolerance to the presence of some metals, without any symptoms of oxidative stress or damage to cell membrane [52]. The plant, incubated briefly in the solutions with large lead concentrations $\left(0.24\right.$ and $\left.0.48 \mathrm{mmol} / \mathrm{dm}^{3}\right)$, did not show reduction of chlorophyll $a$ and chlorophyll $b$, and the "ageing" symptoms occurred only after 168 hours [53]. It was also confirmed that after 5 days of incubation in $\mathrm{Ni}$ solution with concentration of $0.01 \mathrm{mmol} / \mathrm{dm}^{-3}$, there was no slowing down of growth or reduction of the quantity of photosynthetic dyes; at greater concentrations of this metal, the plant activates defence mechanisms, among others, the increase of biosynthesis of the compounds containing thiols [54]. Macrophytes Elodea canadensis and Salvinia sp. immersed in a ferrous solution with concentration of 
$0.09 \mathrm{mmol} / \mathrm{dm}^{-3}$ after 10 days did not show reduction of growth or any other symptoms of toxic influence of the metal, contrary to $\mathrm{Ni}$ and $\mathrm{Cu}$ solutions, which after 5 days caused morphological changes in the tested macrophytes [30]. Laboratory tests also showed that $\mathrm{Ni}$ cations, within concentration range from 0.07 to $1.7 \mathrm{mmol} / \mathrm{dm}^{-3}$, slow down metabolism of nutritive compounds, among others, phosphorus and nitrogen [55].

Monthly observations of the external changes in Elodea canadensis kept in the solution with gradually increasing cadmium concentration up to $0.1 \mathrm{mmol} / \mathrm{dm}^{-3}$ showed that the plant growth was stopped, compared with the control sample. The macrophyte had thinner stems and less developed leaves. Division and growth of chloroplasts were also slowed down, photosynthesis activity was reduced and organisation of cell membrane build up was disturbed [56]. Similar tests showed that slowing down the growth of Elodea canadensis could also be noticed in copper salts solutions, within concentration range from 0.016 to $0.16 \mathrm{mmol} / \mathrm{dm}^{-3}$, in which the tested samples were incubated for 25 days [57]. Toxic influence of $\mathrm{Cu}$ on this macrophyte was also confirmed by other experiments [54].

Tests were also carried out of the influence of cadmium and lead on cellular ultrastructures of Elodea canadensis. It was confirmed that these metals cause changes in the cellular organisation of the plant. Also swelling of chloroplasts was noticed, in consequence of the changes in thylakoids structure. It was also noticed that the stress caused by cadmium cations activated proteins induction - HSP 70 antibodies, belonging to chaperones, the so called chaperone proteins. At a concentration of $\mathrm{Cd} 0.01 \mathrm{mmol} / \mathrm{dm}^{-3}$, there was a $25 \%$ increase of antibodies and at the concentration of $\mathrm{Cd} 0.1 \mathrm{mmol} / \mathrm{dm}^{-3}$, the antibodies increase was $70 \%$. The authors assume that the chaperones can be responsible for the resistance of Elodea canadensis on the toxic influence of $\mathrm{Pb}$ and $\mathrm{Cd}$. This gives it an advantage over other macrophytes and the possibility to survive in the conditions lethal to other water plant species [58].

Other tests showed that Elodea canadensis binds in its cell membranes approximately $70 \% \mathrm{Cd}$ from the solution with concentration of $0.6 \mu \mathrm{mol} / \mathrm{dm}^{-3}, 30 \% \mathrm{Zn}$ from the solution with concentration of $30 \mu \mathrm{mol} / \mathrm{dm}^{-3}$ and $50 \% \mathrm{Cu}$ from the solution with a concentration of $1.0 \mu \mathrm{mol} / \mathrm{dm}^{-3}$. It was confirmed that most of the accumulated zinc and copper is transported through a cell membrane inside a cell, whereas cadmium remains in the cell membrane of the plant. $\mathrm{Zn}$ and $\mathrm{Cu}$ are used, among others, to produce the enzyme needed in synthesis of other, physiologically active particles [52].

Myriophyllum spitacum is another frequently tested macrophyte. With the use of infrared spectroscopy with Fourier transformation (FT-IR) on the example of lead, the function groups present on the surface of this macrophyte were identified. Carboxyl, carbonyl and hydroxyl groups were identified, responsible for fixing cations. Involvement of aromatic fatty acids in the process was also suggested [28]. Thanks to the same method, it was confirmed that carboxyl groups in cell membrane of Myriophyllum spitacum are responsible for fixing copper [29].

In macrophytes Myriophyllum aquaticum collected from the river Xanaes in Argentina, polluted by waters from fields containing, among others, $\mathrm{Co}, \mathrm{Cu}, \mathrm{Fe}, \mathrm{Mn}, \mathrm{Ni}, \mathrm{Pb}$ and $\mathrm{Zn}$, a decrease in photosynthetic pigments quantity in chlorophyll $a$ and $b$ and damage of its structure were observed. It was stated that the phenomenon may be caused by replacement of magnesium ions by heavy metals in chlorophyll particles, which results in reduced catchment of photons and limited photosynthesis process. Some heavy metals, even at low concentrations, can cause oxidative stress, which stops chlorophyll biosynthesis and 
accelerates lipids pre-oxidation, which leads to damage of cellular membranes. The influence of heavy metals on the changes of physical and chemical parameters of the tested organisms was also emphasised [59].

A relatively high resistance of Elodea canadensis and Myriophyllum aquaticum to the content of heavy metals in their environment and the fact that they can sorb cations via all surface directly from water (similarly to lichens and mosses used in biomonitoring of atmospheric aerosol pollution $[60,61]$ ) shows that they can be used in the biomonitoring of surface waters pollution with these analytes.

\section{Use of macrophytes in biomonitoring of surface waters}

Numerous bioindicators and biomonitors, among others algae [62, 63], water animals $[64,65]$ and macrophytes $[54,66]$ are used to assess pollution of water environment. The main objectives of biomonitoring research of surface waters are the assessment of reservoirs pollution, identifying sources of pollution, long-term monitoring in order to define the dynamics of the changes, defining consequences of pollution for biocenosis and comparative studies between different elements of the ecosystem.

Water plants used in biomonitoring should meet the defined criteria, among others, collect large amounts of pollution without damaging themselves, be common in the studies area, be easy to identify and collect for the purpose of studies and, in order to asses seasonal changes, should have a relatively long vegetation period [67-69]. Quantitative assessment of reservoirs pollution also requires that a biomonitor shows statistically relevant correlations between concentration of analytes collected in it, and the concentration in water and/or bottom sediments.

There is a variety of different fresh water reservoirs in nature. They can be divided into natural ones, such as lakes, rivers, streams, natural ponds and marshes, and anthropogenic reservoirs, such as dam reservoirs, artificial ponds, canals and melioration ditches [7]. Many biomonitoring studies of fresh water ecosystems have been carried out with the use of immersed or floating water plants as indicators.

One of the objectives of such studies is to compare the correlations between concentrations of analytes accumulated in various plants and their anatomical parts with concentrations of these analytes in water and bottom sediments. The example includes studies of heavy metals pollutions, ie $\mathrm{Cu}, \mathrm{Zn}, \mathrm{Cd}$ and $\mathrm{Pb}$ of rivers and water reservoirs in western and central Slovakia. During these studies 21 types of water plants were used, among others: Batrachium aquatile, Batrachium penicillatum, Ceratophyllum demersum, Elodea nuttallii, Lemna minor, Myriophyllum spicatum, Potamogeton nodosus and Potamogeton pectinatus. The obtained results show differentiated level of plants pollution in the studied water reservoirs. The largest average concentrations of $\mathrm{Cu}, \mathrm{Zn}$ and $\mathrm{Cd}$ were identified in Batrachium aquatile, whereas $\mathrm{Pb}$ in Fontinalis antipyretica. From the studied types, higher concentrations of heavy metals were observed in the immersed plants, in comparison with the free-floating surface plants [70]. This has been confirmed by the studies published in other works $[44,45]$.

Elodea canadensis Michx. was used during the studies carried out in four eutrophic lakes in southern Finland. In the leaves, sprouts and roots of this macrophyte as well as in bottom sediments of these reservoirs, concentrations of $\mathrm{Cr}, \mathrm{Mn}, \mathrm{Fe}, \mathrm{Ni}, \mathrm{Cu}$ and $\mathrm{Zn}$ were analysed. The obtained results show that concentrations of heavy metals are different in 
different parts of plants. Elodea canadensis accumulates $\mathrm{Fe}$ and $\mathrm{Cu}$ best in roots and $\mathrm{Cr}, \mathrm{Mn}$ and $\mathrm{Ni}$ in leaves. Zn concentration was similar in all parts of the plant. Concentration of the analysed metals in bottom sediments was comparable to their concentration in plants, except for $\mathrm{Mn}[71]$.

In Moldavia, the river Dniestr waters were analysed for mercury contamination. Several water plants were used for that purpose: Potamogeton pectinatus L., Myriophyllum verticillatum L., Potamogeton perfoliatus L., Elodea canadensis Michx. and Ceratophyllum demersum L. The studies showed that these plants can be successfully used as bioindicators of $\mathrm{Hg}$ pollution in surface waters. It was also shown that there is an important correlation of $\mathrm{Hg}$ content in bottom sediments, water and biomass of the studied plants [72].

Pollution with $\mathrm{Cu}, \mathrm{Zn}, \mathrm{Cd}$ and $\mathrm{Pb}$ of the river Nile waters was analysed in Egypt. The metals were studied in six water plants: Ceratophyllum demersum L., Echinochloa pyramidalis (Lam.), Eichhornia crassipes (Mart.), Myriophyllum spicatum L., Phragmites australis (Cav.) and Typha domingensis (Pers.) as well as in bottom sediments and water. Concentrations of heavy metals in water, sediments and plants were changing in line with the following order: $\mathrm{Zn}>\mathrm{Cu}>\mathrm{Pb}>\mathrm{Cd}$. Seasonal nature of concentration changes of the studied analytes was pointed out. The ability to accumulate metals by the studied plants was changing in line with the following order: $C$. demersum $>E$. crassipes $>M$. spitacum $>$ E. pyramidalis $>$ T. domingensis $>$ P. australis. On the basis of the obtained results, it was confirmed that in comparison with sprouts, the roots of all studied plant types contain greater concentration of $\mathrm{Cu}$ and $\mathrm{Zn}$, whereas the leaves contain the largest concentrations of $\mathrm{Pb}$. Cd concentrations in different plant organs are comparable, except for M. spicatum, in which the largest Cd concentrations were observed in leaves [66].

Another example is the studies carried out in south-eastern France, where the plants Elodea canadensis and Elodea nuttallii to assess pollution with $\mathrm{S}, \mathrm{Cr}, \mathrm{Mn}, \mathrm{Fe}, \mathrm{Ni}, \mathrm{Cu}, \mathrm{Zn}$, $\mathrm{Cd}$ and $\mathrm{Pb}$ were used. Concentration of the analytes was assessed for two years in water (a stream and two ponds), bottom sediments and biomass of the studied plants. It was found out that the analytes accumulation was influenced by the location of samples taking but also the analyte type and season of the year. It was also shown that the sorption characteristics of E. canadensis and E. nuttallii are comparable [73].

Another example of biomonitoring studies with the use of water plants are the studies carried out in New Zealand, which covered waters in the volcanic region of Taupo (geothermal area Tokaan and upper and lower section of the river Waikato). During these studies, 16 types of water plants were used, among others Ceratophyllum demersum, Elodea canadensis, Lemma minor, Myriophyllum propinquum, Polygonum hydropiper, Callitriche petriei, Egeria densa. Arsenic concentration was assessed in plants, bottom sediments and water. It was discovered that As concentration in Ceratophyllum demersum was 100 times larger than in bottom sediments and 1000 times larger than in water. Moreover, it was confirmed that As concentration in water, bottom sediments and the studied plants was twice larger than the water quality standard applied in New Zealand [74].

In Poland, similar studies have been carried out with the use of Elodea canadensis Michx. Contamination with heavy metals was studied in three small rivers in the river Odra catchment area: Row Polski, Kanal Polski and Row Slaski. An increased concentration of the following metals was identified: $\mathrm{Al}, \mathrm{V}, \mathrm{Cr}, \mathrm{Mn}, \mathrm{Co}, \mathrm{Ni}, \mathrm{Cu}, \mathrm{Zn}, \mathrm{Cd}$ and $\mathrm{Pb}$. It was found out that they originate mainly from communal sewage discharged to the rivers. Also the positive correlations between concentrations of $\mathrm{Al}, \mathrm{Cr}$ and $\mathrm{Cu}$ in bottom sediments, water 
and the studied macrophytes were emphasised [75]. Studies were carried out near Wroclaw with the use of several types of water plants, aiming at assessment of water quality and identifying potential sources of contamination. It was found out that average concentration of the identified heavy metals $(\mathrm{Cr}, \mathrm{Co}, \mathrm{Ni}, \mathrm{Cu}, \mathrm{Zn}, \mathrm{Cd}, \mathrm{Hg}$ and $\mathrm{Pb}$ ) exceed the allowed concentrations for waters, which are the source of potable water. They originate mainly from a pesticide factory in Brzeg Dolny and from a power plant and steel mill sewage. Comparison of concentrations of the studied analytes in the individual groups of water plants showed that the largest concentrations of $\mathrm{Cr}, \mathrm{Co}, \mathrm{Ni}, \mathrm{Cu}$ and $\mathrm{Zn}$ were present in totally immersed plants with root systems. In turn, the largest concentrations of $\mathrm{Pb}$ were observed in the plants floating under the water surface. The largest concentrations of $\mathrm{Cd}$ and $\mathrm{Hg}$ were observed in the macrophytes, where leaves float on the water surface. Also, the correlation between concentration of $\mathrm{Cu}, \mathrm{Zn}$ and $\mathrm{Cd}$ in the plant biomass and concentration of $\mathrm{Cu}$ in water and between concentration of $\mathrm{Ni}$ and $\mathrm{Cd}$ in the plants and concentration of $\mathrm{Ni}$ in water were pointed out [76]. Biomonitoring studies of two small rivers were carried out: Olobok and Pilawa, located in south-western Poland. The following macrophytes were used in the studies: Elodea canadensis, Callitriche verna, Potamogeton crispus, Potamogeton natans, Ceratophyllum demersum, Polygonum amphibium and Veronica beccabunga [77].

Studies of surface waters pollution with the use of macrophytes were also carried out in Czech Republic, where on the basis of the analytes concentrations accumulated in: Potamogeton crispus, Potamogeton. pectinatus, Myriophyllum spicatum, Elodea canadensis and Polygonum amphibium assessment of the pollution of the river Dyi and its catchment area [78], in Romania (samples of Ceratophyllum sp., Myriophyllum sp., Potamogeton sp. were taken from waters in the Danube delta) [65], in the former Yugoslavia (samples: Ceratophyllum demersum L., Myriophyllum spicatum L. and Nymphoides flava Hill. were taken in the Provala lake waters) [45], in Serbia, in the canal system Danube - Tisa - Danube (samples for tests collected: Ceratophyllum demersum L., Nymphaea alba L., Phragmites communis Trin., Trapa longicarpa Jank., Typha angustifolia L., Elodea canadensis L., Phragmites communis Trin. Potamogeton pectinatus) [79] and waters of the Danube (samples taken: Potamogeton perfoliatus, Potamogeton pectinatus, Potamogeton lucens, Ceratophyllum demersum [80], in Moldavia (samples: Myriophyllum verticillatum L., Potamogeton perfoliatus L., Potamogeton pectinatus L., Elodea canadensis Michx. collected in a reservoir in Dubossary) [81], in Greece (samples taken: Ceratophyllum demersum, Myriophyllum spicatum, Potamogeton nodosus and Lemna minor) [82], in Turkey, where on the basis of analytes accumulated in Potamogeton pectinatus L., pollution of marshes in the central region was studied [83], in China (samples: Potamogeton pectinatus L. and Potamogeton malaianus Miq. taken from the river Donghe) [36] and in Argentina, where from the river Xanaes near Cordoba samples of Myriophyllum aquaticum were taken [59].

As evident from the quoted examples, at the current stage of the studies, it is essential to identify correlations between the concentrations of analytes accumulated in various plants and their anatomical parts, with concentrations of these analytes in water and bottom sediments. The studies show that different parts of plants demonstrate sorption preferences regarding different metals present in the form of ions in water and accumulated sediments, which permits selective assessment of contamination with heavy metals of these ecosystem components. However, it is hard to definitely asses the correlations presented in the articles, 
due to lack of information on the errors count; however, the authors clearly declare that macrophytes can be successfully used in biomonitoring of heavy metal pollution in surface waters and bottom sediments.

\section{Use of water plants for removal of heavy metals from water and sewage}

Phytoremediation is a technology of purification based on the use of higher plants and the related microorganisms in order to clean or stop spreading pollution in the environment [84]. Phytoremediation techniques use natural processes, during which plants together with their risospheric symbiants accumulate, deactivate, detoxify or evaporate pollution from soil, water or air [85-88], however, in reality, these processes are much more complex [85, 86].

The water plants used in phytoremediation processes should be tolerant to a large concentration of xenobiotics and should have the ability to accumulate several contaminants simultaneously, high level of pollution biodegradability, even at a relatively low pollution level, fast growth, large biomass production, resistance to diseases and pest as well as difficult environment conditions. Certain plants have the ability to accumulate pollution by fixing it in the structure of own cells; others, in turn, can absorb toxins as a natural effect of adjustment to difficult conditions in a polluted environment [86].

In recent years, more attention is paid to the use of various types of water plants in the processes of cleaning waters and sewage, mainly from heavy metals. The biggest advantage of the phytoremediation process, as the method for removing heavy metals, is low costs versus classical cleaning methods, its simplicity, which improves efficiency and makes it economically feasible. There are no special requirements regarding the supply of nutritive elements to the plants, which take part in the cleaning process [89].

The studies regarding the use of water plants to clean water and sewage aim at assessing the ability of water plants to remove heavy metals from solutions, the speed of the process, the influence of large concentrations of analytes on their morphology and physiology and assessment of the possibility of desorption of heavy metals from plants, in order to reuse the same biomass several times.

Laboratory tests were carried out, which showed that certain types of water plants are capable of hyperaccumulating heavy metals from solutions. One of the plants with such characteristics is Elodea canadensis Michx. The plant accumulates large amounts of $\mathrm{Cu}, \mathrm{Zn}$ and $\mathrm{Cd}$ and, as was also confirmed, large concentration of $\mathrm{Cu}$ and $\mathrm{Zn}$ in its cells does not stop growth of the plant and further accumulation of metals [52]. Other studies also showed the ability of this macrophyte to hyperaccumulate $\mathrm{Cr}$ [90]. Good sorption characteristics of $\mathrm{Cu}, \mathrm{Zn}, \mathrm{Cd}$ and $\mathrm{Pb}$ from solutions are demonstrated by: Lemna minor, Elodea canadensis and Leptodictyum riparium [91]. Studies were also carried out with Ceratophyllum demersum. From the solution with initial concentrations: $4.866 \mu \mathrm{mol} \mathrm{Cr} / \mathrm{dm}^{3}$, $6.63 \mu \mathrm{mol} \mathrm{Mn} / \mathrm{dm}^{3}, 74.91 \mu \mathrm{mol} \mathrm{Fe} / \mathrm{dm}^{3}, 1.338 \mu \mathrm{mol} \mathrm{Cu} / \mathrm{dm}^{3}$ and $7.784 \mu \mathrm{mol} \mathrm{Pb} / \mathrm{dm}^{3}$, after 15 days of exposure, the plant accumulated $92 \% \mathrm{Cr}, 80 \% \mathrm{Mn}, 95 \% \mathrm{Fe}, 90 \% \mathrm{Cu}$ and $70 \% \mathrm{~Pb}[28]$.

Good sorption characteristics can also be attributed to Lemna minor. Using this macrophyte, from lead solution with initial concentration of $0.024-0.048 \mathrm{mmol} / \mathrm{dm}^{3}$ on average $76 \% \mathrm{~Pb}$ was removed, whereas from nickel solutions with initial concentrations of 0.43-0.86 $\mathrm{mmol} / \mathrm{dm}^{3}$ on average $82 \%$ of the metal was removed [92]. Other studies show 
that Lemna minor can also be used to remove $\mathrm{Cu}$ and $\mathrm{Cd}$ from solutions [93] and with low concentrations, $\mathrm{Cr}, \mathrm{Zn}$ and As [38, 94].

Table 2 presents information on macrophyte studies regarding sorption characteristics of selected metals and literature containing descriptions of the studies.

Table 2

Studies of macrophytes in order to assess their ability to accumulate heavy metals

\begin{tabular}{|c|c|c|}
\hline Aquatic plants & Heavy metal & References \\
\hline Ceratophyllum demersum & $\mathrm{Cu}, \mathrm{Zn}, \mathrm{Pb}$ & {$[26]$} \\
\hline \multirow{4}{*}{ Elodea canadensis } & $\mathrm{Cr}$ & {$[90]$} \\
\cline { 2 - 3 } & $\mathrm{Pb}$ & {$[95]$} \\
\cline { 2 - 3 } & $\mathrm{Cu}, \mathrm{Zn}, \mathrm{Cd}$ & {$[52]$} \\
\cline { 2 - 3 } Lemna gibba & $\mathrm{Cu}, \mathrm{Zn}, \mathrm{Cd}, \mathrm{Pb}$ & {$[91]$} \\
\hline \multirow{4}{*}{ Lemna minor } & $\mathrm{As}, \mathrm{U}$ & {$[96]$} \\
\cline { 2 - 3 } & $\mathrm{As}$ & {$[97]$} \\
\hline \multirow{2}{*}{ Myriophyllum spitacum } & $\mathrm{Cu}, \mathrm{Zn}, \mathrm{Cd}, \mathrm{Pb}$ & {$[98]$} \\
\hline & $\mathrm{As}$ & {$[38]$} \\
\cline { 2 - 3 } & $\mathrm{Cr}, \mathrm{Cu}, \mathrm{Zn}, \mathrm{Cd}$ & {$[92]$} \\
\cline { 2 - 3 } & $\mathrm{Pb}$ & {$[93]$} \\
\cline { 2 - 3 } & $\mathrm{Cu}, \mathrm{Cd}$ & {$[94]$} \\
\cline { 2 - 3 } & $\mathrm{As}, \mathrm{Hg}$ & {$[23]$} \\
\hline Potamogeton natans & $\mathrm{Cr}, \mathrm{Co}, \mathrm{Ni}, \mathrm{Cu}, \mathrm{Zn}, \mathrm{Pb}$ & {$[30]$} \\
\hline Potamogeton pectinatus & $\mathrm{Cu}$ & {$[99]$} \\
\hline
\end{tabular}

Together with the studies related to the use of sorption characteristics of water plants to clean waters, studies have been carried out regarding the multiple use of biomass. This results from the fact that dead biomass does not lose its surface sorption characteristics. In order to reactivate the surface and deactivate heavy metals, desorption of metal cations and their precipitation in insoluble form are carried out by, for example, bathing biomass in $\mathrm{H}_{2} \mathrm{~S}$, carbonate or sodium bicarbonate and in solutions with metal chelating factor, eg EDTA. Also desorption of metals in acids solutions is carried out [101, 102]. One of the most frequently used desorbing agents is hydrochloric acid. It was confirmed that in $\mathrm{HCl}$ solution with concentration of $0.1 \mathrm{~mol} / \mathrm{dm}^{3}$, approximately $55 \% \mathrm{Cu}, 60 \% \mathrm{Ni}$ and $71-72 \% \mathrm{Co}$ and $\mathrm{Zn}$ desorbed from Myriophyllum spitacum [39]. Selenium desorption efficiency from Lemna minor in $\mathrm{HCl}$ solution with the same concentration amounted to $18 \%$ [48]. Hydrochloric acid $(0.5 \%)$ was successfully used in multiple desorption of copper from the biomass of Ceratophyllum demersum, Myriophyllum brasiliensis, Eichhornia crassipes, Potamogeton lucens and Salvinia herzogii [15].

The presented studies results show that phytoremediation of water and sewage with the use of immersed and floating water plants can be an effective and economically feasible method of cleaning surface waters and additional cleaning of industrial sewage.

\section{Summary and conclusions}

Biomonitoring studies have become more and more popular in assessing pollution of different environment matrices during recent years. The method has many advantages, among others availability of research material, easy and cheap method of sample taking and 
the fact that biomonitors accumulate bioaccessible forms of pollution. Studies regarding the use of plants in the remediation processes of soil, air and water have been under way for many years. Similarly, it is a cheap and environment-friendly cleaning method based on, among others, accumulation in plants or deactivation of pollution.

It was confirmed that certain water plants, thanks to their anatomical structure, good sorption characteristics and great resistance to pollution, can be used for both biomonitoring and phytoremediation processes of water and sewage.

The main objectives of the studies of the use of macrophytes in biomonitoring is assessment of water quality, identification of pollution sources and assessment of quality changes of water ecosystems in time. The most frequently used macrophytes in biomonitoring are Elodea canadensis, Ceratophyllum demersum, Lemna minor and the types within the Potamogeton and Myriophyllum genus. Also, the possibilities of using these plants in phytoremediation processes are analysed.

Still, the correlations between concentrations of pollution in water plants and waters, in which they vegetate, are being studied. The presented examples of research show, in some cases, considerable differences of results, which may depend on different the experiment conditions and lack of recognition of abiotic and biotic factors, which influence sorption processes. However, the authors clearly point out that macrophytes can in future be successfully used in the biomonitoring of heavy metals pollution in surface waters and bottom sediments.

\section{References}

[1] Szmeja J. Przewodnik do badań roślinności wodnej. Gdańsk: Wyd Uniwersytetu Gdańskiego; 2006.

[2] Gessner F. Hydrobotanik. Berlin: Bd. VEB Deutsche Verlg. Wissenschaften; 1959.

[3] Rabajczyk A, Jóźwiak MA. The possibilities of using macrophytes as bioindicators of heavy metals occurring in sediments. Monit Środow Przyrod. 2008;9:19-26

[4] Wołek J. Występowanie i rozmieszczenie roślin wodnych i szuwarowych na obszarze zespołu zbiorników wodnych Czorsztyn - Niedzica i Sromowe Wyżne przez spiętrzeniem wody. Fragm Flor Geobot., Series Polonica. 1996;3:189-203.

[5] Gabler D, Szoszkiewicz K. Ecological status assessment of rivers using macrophytes on selected examples. Scientific Review. Eng and Environ Sci. 2011;52:75-83.

[6] Stańczykowska A. Ekologia naszych wód. Warszawa: Wyd Szkolne i Pedagogiczne; 1997.

[7] Strzelec M, Spyra A, Serafiński W. Biologia wód śródlądowych: skrypt dla studentów I i II stopnia na kierunkach biologia i ochrona środowiska. Katowice: Wyd. Uniwersytetu Śląskiego; 2010.

[8] Polanowska M. Rośliny wodne. Warszawa: Wyd Szkolne i Pedagogiczne; 1992.

[9] Kłosowski G, Kłosowski S. Rośliny wodne i bagienne. Warszawa: MULTICO; 2001.

[10] Staniszewski R, Szoszkiewicz J. Rośliny stanowisk wilgotnych i wodnych. Poznań: Wyd. Uniwersytetu Przyrodniczego w Poznaniu; 2009.

[11] Matuszkiewicz W. Przewodnik do oznaczania zbiorowisk roślinnych Polski. Warszawa: Wyd Nauk PWN; 2001.

[12] Szoszkiewicz K, Jusik S, Zgoła T. Klucz do oznaczania makrofitów dla potrzeb oceny stanu ekologicznego wód powierzchniowych w Polsce. Warszawa: Biblioteka Monitoringu Środowiska; 2008.

[13] Guilizzoni P. The role of heavy metals and toxic materials in the physiological ecology of submersed macrophytes. Aquatic Botany. 1991;41(1-3):87-109. DOI: 10.1016/0304-3770(91)90040-C.

[14] Schneider IAH, Rubio J, Smith RW. Biosorption of metals onto plant biomass: exchange adsorption or surface precipitation? Internat J Mineral Process. 2001;62(1-4):111-120. PII: S0301-7516(00)00047-8.

[15] André I, Schneider H, Rubio J. Sorption of heavy metal ions by the nonliving biomass of freshwater macrophytes. Environ Sci Technol. 1999;33:2213-2217.

[16] Wang G, Fuerstenau MC, Smith RW. Sorption of heavy metals onto nonliving water hyacinth roots. Mineral Processing and Extractive Metallurgy Review: An Internat J. 1998;19(1):309-322. DOI: $10.1080 / 08827509608962448$. 
[17] Schneider IAH, Smith RW, Rubio J. Effect of mining chemicals on biosorption of $\mathrm{Cu}$ (II) by the non-living biomass of the macrophyte Potamogeton lucens. Miner Eng. 1999;12(3):255-260. DOI: 10.1016/S08926875(99)00003-5.

[18] Lacher C, Smith RW. Sorption of $\mathrm{Hg}(\mathrm{II})$ by Potamogeton natans dead biomass. Miner Engineer. 2002;15:187-191. PII: S08 92-6 875(01)00212- 6.

[19] Miretzky P, Saralegui A, Cirelli AF. Simultaneous heavy metal removal mechanism by dead macrophytes. Chemosphere. 2006;62:247-254. DOI: 10.1016/j.chemosphere.2005.05.010.

[20] Elifantz H, Tel-Or E. Heavy metal biosorption by plant biomass of the macrophyte Ludwigia Stolonifera. Water, Air, and Soil Pollut. 2002;141(1-4):207-218. DOI: 10.1023/A:1021343804220.

[21] Veglio F, Beolchini F. Removal of metals by biosorption: a review. Hydrometallurgy. 1997;44(3):301-316. DOI: 10.1016/S0304-386X(96)00059-X.

[22] Chojnacka K. Biosorption and bioaccumulation - the prospect for practical appications. Environ Internation. 2010;36:299-307. DOI:10.1016/j.envint.2009.12.001.

[23] Keskinkan O, Goksu MZL, Yuceer A, Basibuyuk M, Forster CF. Heavy metal adsorption characteristics of a submerged aquatic plant (Myriophyllum spicatum) Process Biochem. 2003;39:179-183. DOI: 10.1016/S0032-9592(03)00045-1.

[24] Das N, Vimala R, Karthika P. Biosorption of heavy metals - An overview. Indian J Biotechnol. 2008;7:159-169.

[25] Keskinkan O, Goksu MZL, Yuceer A, Basibuyuk M. Comparison of the adsorption capabilities of Myriophyllum spicatum and Ceratophyllum demersum for zinc, copper and lead. Eng Life Sci. 2007;7(2):192-196. DOI: 10.1002/elsc.200620177.

[26] Keskinkan O, Goksu MZL, Basibuyuk M, Forster CF. Heavy metal adsorption properties of a submerged aquatic plant (Ceratophyllum demersum). Bioresour Technol. 2004;92:197-200. DOI: 10.1016/j.biortech.2003.07.011

[27] Ngayila N, Basly J-P, Lejeune A-H, Botineau M, Baudu M. Myriophyllum alterniflorum DC., biomonitor of metal pollution and water quality. Sorption/accumulation capacities and photosynthetic pigments composition changes after copper and cadmium exposure. Sci Total Environ. 2007;373:564-571. DOI: 10.1016/j.scitotenv.2006.11.038.

[28] Rai UN, Sinha S, Tripathi RD, Chandra P. Wastewater treatability potential of some aquatic macrophytes: Removal of heavy metals. Ecol Eng. 1995;5:5-12. SSDI:0925-8574(95)00011-9.

[29] Li G, Xue P, Yan C, Li Q. Copper biosorption by Myriophyllum spicatum: Effects of temperature and $\mathrm{pH}$. Korean J Chem Eng. 2010;27(4):1239-1245. DOI: 10.1007/s11814-010-0183-X.

[30] Yan C, Wang S, Zeng A, Jin X, Xu Q, Zhao J. Equilibrium and kinetics of copper(II) biosorption by Myriophyllum spicatum L. J Environ Sci. 2005;17(6):1025-1029.

[31] Kähkönen MA, Manninen PKG. The uptake of nickel and chromium from water by Elodea canadensis at different nickel and chromium exposure levels. Chemosphere. 1998;36(6):1381-1390.

[32] Sivaci RD, Sivaci A, Sőkmen M. Biosorption of cadmium by Myriophyllum spicatum L. and Myriophyllum triphyllum orchard. Chemosphere. 2004;56:1043-1048. DOI: 10.1016/j.chemosphere.2004.05.032.

[33] Mechora Š, Cuderman P, Stibilj V, Germ M. Distribution of Se and its species in Myriophyllum spicatum and Ceratophyllum demersum growing in water containing Se(VI). Chemosphere. 2011;84:1636-1641. DOI: 10.1016/j.chemosphere.2011.05.024.

[34] Khang HV, Hatayama M, Inoue C. Arsenic accumulation by aquatic macrophyte coontail (Ceratophyllum demersum L.) exposed to arsenite, and the effect of iron on the uptake of arsenite and arsenate. Environ and Experim Botany. 2012;83:47-52. DOI: 10.1016/j.envexpbot.2012.04.008.

[35] Mishra S, Srivastava S, Tripathi RD, Kumar R, Seth CS, Gupta DK. Lead detoxification by coontail (Ceratophyllum demersum L.) involves induction of phytochelatins and antioxidant system in response to its accumulation. Chemosphere. 2006;65:1027-1039. DOI: 10.1016/j.chemosphere.2006.03.033.

[36] Peng K, Luo C, Lou L, Li X, Shen Z. Bioaccumulation of heavy metals by the aquatic plants Potamogeton pectinatus L. and Potamogeton malaianus Miq. and their potential use for contamination indicators and in wastewater treatment. Sci Total Environ. 2008;392(11): 22-29. DOI: 10.1016/j.scitotenv.2007.11.032.

[37] Begum A, HariKrishna S. Bioaccumulation of trace metals by aquatic plants. Internat $\mathbf{J}$ of Chem Tech Research. 2010;2(1):250-254.

[38] Sekomo CB, Rousseau DPL, Saleh SA, Lens PNL. Heavy metal removal in duckweed and algae ponds as a polishing step for textile wastewater treatment. Ecol Eng. 2012;44:102-110. DOI: 10.1016/j.ecoleng.2012.03.003. 
[39] Lesage E, Mundia C, Rousseau DPL, Van de Moortel AMK, Du Laing G, Meers E, et al. Sorption of Co, $\mathrm{Cu}, \mathrm{Ni}$ and $\mathrm{Zn}$ from industrial effluents by the submerged aquatic macrophyte Myriophyllum spicatum L. Ecol Eng. 2007;30:320-325. DOI: 10.1016/j.ecoleng.2007.04.007.

[40] Wang TC, Weissman JC, Ramesh G, Varadarajan R, Benemann JR. Parameters for removal of toxic heavy metals by water milfoil (Myriophyllum spicatum). Bulletin of Environ Contamin and Toxicol. 1996;57(5):779-786.

[41] Rajfur M, Kłos A, Wacławek M. Sorption properties of algae Spirogyra sp. and their use for determination of heavy metal ions concentrations in surface water. Bioelectrochemistry. 2010;80:81-86. DOI: 10.1016/j.bioelechem.2010.03.005.

[42] Rajfur M, Kłos A, Wacławek M. Sorption of copper(II) ions in the biomass of alga Spirogyra sp. Bioelectrochemistry. 2012;87:65-70. DOI: 10.1016/j.bioelechem.2011.12.007.

[43] Maleva MG, Nekrasova GF, Bezel VS. The response of hydrophytes to environmental pollution with heavy metals. Russ J of Ecol. 2004;35(4):230-235. DOI: 10.1023/B:RUSE.0000033791.94837.

[44] Pajevic S, Vuckovic M, Stankovic Z, Krstic B, Kevresan Z, Radulovic S. The content of some macronutrients and heavy metals in aquatic macrophytes of three ecosystems connected to the Danube in Yugoslavia. Arch Hydrobiol Suppl. 2002;141(1-2):73-83.

[45] Stanković Ž, Pajević S, Vučković M, Stojanović S. Concentrations of trace metals in dominant aquatic plants of the Lake Provala (Vojvodina, Yugoslavia). Biologia Plantarum. 2000;43(4):583-585. DOI: 10.1023/A:1002806822988.

[46] Mazej Z, Germ M. Trace element accumulation and distribution in four aquatic macrophytes. Chemosphere. 2009;74:642-647. DOI: 10.1016/j.chemosphere.2008.10.019.

[47] Kabziński AKM. Metale ciężkie. Cz. II. Emisja i wpływ metali na środowisko. Bioskop. 2007;3:5-10.

[48] González-Acevedo ZI, Olguín MT, Rodríguez-Martínez CE, Frías-Palos H. Sorption and desorption processes of selenium(VI) using non-living biomasses of aquatic weeds in horizontal flow. Water, Air, \& Soil Pollut. 2012;223(7):4119-4128. DOI: 10.1007/s11270-012-1178-5.

[49] Fritioff $\AA$, Kautsky L, Greger M. Influence of temperature and salinity on heavy metal uptake by submersed plants. Environ Pollut. 2005;133:265-274. DOI: 10.1016/j.envpol.2004.05.036.

[50] Kabata-Pendias A, Pendias H. Geochemia pierwiastków śladowych. Warszawa: Wyd Nauk PWN; 1999.

[51] Formicki G. Metale ciężkie w środowisku wodnym: właściwości toksyczne, biologiczne, dostępność i kumulacja w tkankach zwierząt. Kraków: Wyd Nauk Uniwersytetu Pedagogicznego w Krakowie; 2010.

[52] Nyquist J, Greger M. Uptake of $\mathrm{Zn}, \mathrm{Cu}$, and $\mathrm{Cd}$ in metal loaded Elodea canadensis. Environ and Exper Botany. 2007;60:219-226. DOI: 10.1016/j.envexpbot.2006.10.009.

[53] Temel M. The effects of various concentrations of lead to chlorophyll a and chlorophyll b of Elodea canadensis Michx. BAÜ Fen Bil Enst Dergisi. 2005;7(2):12-18.

[54] Malec P, Maleva M, Prasad MNV, Strzałka K. Copper toxicity in leaves of Elodea canadensis Michx. Bull Environ Contam Toxicol. 2009;82:627-632. DOI: 10.1007/s00128-009-9650-7.

[55] Kähkönen MA, Kairesalo T. The effects of nickel on the nutrient fluxes and on the growth of Elodea canadensis. Chemosphere. 1998;37(8): 1521-1530. PII: 800456535(98)00147-7.

[56] Vecchia FD, La Rocca N, Moro I, De Faveri S, Rascio CAN. Morphogenetic, ultrastructural and physiological damages suffered by submerged leaves of Elodea canadensis exposed to cadmium. Plant Sci. 2005;168:329-338. DOI: 10.1016/j.plantsci.2004.07.025.

[57] Mal TK, Adorjan P, Corbett AL. Effect of copper on growth of an aquatic macrophyte, Elodea canadensis. Environ Pollut. 2002;120:307-311. PII: S0269-7491(02)00146-X.

[58] Sergio E, Cobianchi RS, Sorbo S, Conte B, Basile A. Ultrastructural alterations and HSP 70 induction in Elodea canadensis Michx. exposed to heavy metals. Caryologia. 2007;60(1-2):115-120.

[59] Harguinteguy CA, Schreiber R, Pignata ML. Myriophyllum aquaticum as a biomonitor of water heavy metal input related to agricultural activities in the Xanaes River (Córdoba, Argentina). Ecol Indicat. 2013;27:8-16. DOI: 10.1016/j.ecolind.2012.11.018.

[60] Kłos A, Rajfur M, Wacławek M, Wacławek W, Wünschmann S, Markert B. Quantitative relations between different concentrations of micro- and macroelements in mosses and lichens: the region of Opole (Poland) as an environmental interface in between Eastern and Western Europe. Int $J$ Environ Health. 2010;4(2/3):98-119. DOI:10.1504/IJENVH.2010.033702.

[61] Kłos A, Rajfur M, Šrámek I, Wacławek M. Use of lichen and moss in assessment of forest contamination with heavy metals in Praded and Glacensis Euroregions (Poland and Czech Republic). Water Air \& Soil Pollut. 2011;222:367-376. DOI:10.1007/s11270-011-0830-9. 
[62] Rajfur M, Kłos A, Waclawek M. Algae utilization in assessment of the large Turawa Lake (Poland) pollution with heavy metals. J Environ Sci and Health Part A. 2010;46: 1401-1408. DOI:10.1080/10934529.2011.606717.

[63] Komulainent SF, Morozov AK. Heavy metal dynamics in the periphyton in small rivers of Kola Peninsula. Water Res. 2010;37(6):874-878. DOI: 10.1134/S0097807810060138.

[64] Birungi Z, Masola B, Zaranyika MF, Naigaga I, Marshal B. Active biomonitoring of trace heavy metals fish using (Oreochromis niloticus) as bioindicator species. The case of Nakivubo wetland along Lake Victoria. Phys and Chem of the Earth. 2007;32(15-18):1350-1358. DOI: 10.1016/j.pce.2007.07.034.

[65] Tudor MI, Tudor M, David C, Teodorof L, Tudor D. Heavy metals concentrations in aquatic environment and living organisms in the Danube delta, Romania. Chemicals as Intent and Accid Global Environ Threats. 2006:435-442.

[66] Fawzy MA, El-sayed Badr N, El-Khatib A, Abo-El-Kassem A. Heavy metal biomonitoring and phytoremediation potentialities of aquatic macrophytes in River Nile. Environ Monit Assess. 2012;184:1753-1771. DOI: 10.1007/s10661-011-2076-9.

[67] Zimny H. Ekologiczna ocena stanu środowiska. Bioindykacja i biomonitoring. Warszawa: Agencja Reklamowo-Wydawnicza A. Grzegorczyk; 2006.

[68] Zhou G, Zhang J, Fu J, Shi J, Jiang G. Biomonitoring: An appealing tool for assessment of metal pollution in the aquatic ecosystem. Anal Chim Acta. 2008;606(2);135-150. DOI:10.1016/j.aca.2007.11.018.

[69] Wardencki W. Bioanalityka w ocenie zanieczyszczenia środowiska. Gdańsk: CEEAM; 2004.

[70] Jamnická G, Hrivnák R, Ot’ahel'ová H, Skoršepa M, Valachovič M. Heavy metals content in aquatic plant species from some aquatic biotopes in Slovakia. Proc 36th Internat Conf of IAD. Wien: Austrian Committee Danube Research/IAD. 2006:336-370.

[71] Kähkönen MA, Pantsar-Kallio M, Manninen PKG. Analysing heavy metal concentrations in the different parts of Elodea canadensis and surface sediment with PCA in two boreal lakes in Southern Finland. Chemosphere. 1997;35(11):2645-2656. PII:S0045-6535(97)00337-8.

[72] Munteanu V, Munteanu G. Biomonitoring of mercury pollution: A case study from the Dniester River. Ecolog Indicat. 2007;7:489-496. DOI:10.1016/j.ecolind.2006.01.002.

[73] Thiébaut G, Gross Y, Gierlinski P, Boiché A. Accumulation of metals in Elodea canadensis and Elodea nuttallii: Implications for plant-macroinvertebrate interactions. Sci Total Environ. 2012;408(22):5499-5505. DOI: 10.1016/j.scitotenv.2010.07.026.

[74] Robinson B, Kim N, Marchetti M, Moni C, Schroeter L, van den Dijssel C, Milne G, Clothier B. Arsenic hyperaccumulation by aquatic macrophytes in the Taupo Volcanic Zone, New Zealand. Environ Experim Botany. 2006;58:206-215. DOI: 10.1016/j.envexpbot.2005.08.004.

[75] Samecka-Cymerman A, Kempers AJ. Biomonitoring of water pollution with Elodea canadensis. A case study of three small Polish rivers with different levels of pollution. Water, Air, \& Soil Pollut. 2003;145(1-4):139-153.

[76] Samecka-Cymerman A, Kempers AJ. Bioaccumulation of heavy metals by aquatic macrophytes around Wrocław, Poland. Ecotoxicol and Environ Safety. 1996; 35(3):242-247.

[77] Samecka-Cymerman A, Kempers AJ. Heavy metals in aquatic macrophytes from two small rivers polluted by urban, agricultural and textile industry sewages SW Poland. Arch Environ Contam Toxicol. 2007;53:198-206. DOI: 10.1007/s00244-006-0059-6.

[78] Žáková Z, Kočková E. Biomonitoring and assessment of heavy metal contamination of streams and reservoirs in the Dyje/Thaya river basin, Czech Republic. Water Sci Technol. 1999;39(12):225-232.

[79] Pajeviã SP, Vuåkoviã MS, Kevrešan ŽS, Matavulj MN, Radulović SW, Radnović DV. Aquatic macrophytes as indicators of heavy metal pollution of water in DTD canal system. Proc for Natural Sci. 2003;104:51-60. UDC: 581.526.3:581.192]:556.53(497.113).

[80] Pajević S, Borišev M, Rončević S, Vukov D, Igić R. Heavy metal accumulation of Danube river aquatic plants - indication of chemical contamination. Cent Eur J Biol. 2008;3(3):285-294. DOI: 10.2478/s11535-008-0017-6.

[81] Muntyanu GG, Muntyanu VI. Biomonitoring of some heavy metals in the Dubossary (Dubasari) Reservoir. Hydrobiol J. 2006;42(2):87-101.

[82] Sawidis T, Chettri MK, Zachariadis GA, Stratis JA. Heavy metals in aquatic plants and sediments from water systems in Macedonia, Greece. Ecotoxicol Environ Saf. 1995;32(1):73-80.

[83] Demirezen D, Aksoy A. Accumulation of heavy metals in Typha angustifolia (L.) and Potamogeton pectinatus (L.) living in Sultan Marsh (Kayseri, Turkey). Chemosphere. 2004;56:685-696. DOI: 10.1016/j.chemosphere.2004.04.011. 
[84] Tsao DT. Overview of phytotechnologies. Naperville Group Environ Manage J. 2003;78:7-14. DOI: 10.1007/3-540-45991-X_1.

[85] Buczkowski R, Kondzielski I, Szymański T. Metody remediacji gleb zanieczyszczonych metalami ciężkimi. Toruń: Wyd Uniwersytetu Mikołaja Kopernika; 2002.

[86] Marecik R, Króliczak P, Cyplik P. Fitoremediacja - alternatywa dla tradycyjnych metod oczyszczania środowiska. Biotechnologia. 2006;74:88-97.

[87] Rahman MA, Hasegawa H. Aquatic arsenic: Phytoremediation using floating macrophytes. Chemosphere. 2011;83(5): 633-646. DOI: 10.1016/j.chemosphere.2011.02.045.

[88] Pilon-Smits E. Phytoremedation. Ann Rev Plant Biol. 2005;56:15-39.

[89] Parveen S, Arjun B. Bioaccumulation of chromium by aquatic macrophytes Hydrilla sp. \& Chara sp. Pelagia Research Library. 2011;2(1):214-220.

[90] Chandra P, Kulshreshtha K. Chromium accumulation and toxicity in aquatic vascular plants. Botan Rev. 2004;70(3):313-327. DOI: 10.1663/0006-8101(2004)070[0313:CAATIA]2.0.CO;2.

[91] Basile A, Sorbo S, Conte B, Cobianchi RC, Trinchella F, Capasso C, Carginale V. Toxicity, accumulation, and removal of heavy metals by three aquatic macrophytes. Internat $\mathrm{J}$ Phytoremediat. 2012;14(4):374-387. DOI: 10.1080/15226514.2011.620653.

[92] Axtell NR, Sternberg APK, Claussen K. Lead and nickel removal using Microspora and Lemna minor. Bioresour Technol. 2003;89(1):41-48. DOI: 10.1016/S0960-8524(03)00034-8.

[93] Hou W, Chen X, Song G, Wang Q, Chang CC. Effects of copper and cadmium on heavy metal polluted waterbody restoration by duckweed (Lemna minor). Plant Physiol and Biochem. 2007;45(1):62-69. DOI: 10.1016/j.plaphy.2006.12.005.

[94] Mishra VK, Upadhyay AR, Pathak V, Tripathi BD. Phytoremediation of mercury and arsenic from tropical opencast coalmine effluent through naturally occurring aquatic macrophytes. Water, Air, and Soil Pollut. 2008;192(1-4):303-314. DOI: 10.1007/s11270-008-9657-4.

[95] Dogan M, Saygideger SD, Colak U. Effect of lead toxicity on aquatic macrophyte Elodea canadensis Michx. Bull of Environ Contamin and Toxicol. 2009;83(2):249-254. DOI: 10.1007/s00128-009-9733-5.

[96] Mkandawire M, Taubert B, Dudel EG. Capacity of Lemna gibba L. (Duckweed) for uranium and arsenic phytoremediation in mine tailing waters. Internat $\mathrm{J}$ of Phytoremediat. 2004;6(4):347-362. DOI: $10.1080 / 16226510490888884$.

[97] Mkandawire M, Dudel EG. Accumulation of arsenic in Lemna gibba L. (duckweed) in tailing waters of two abandoned uranium mining sites in Saxony, Germany. Sci of The Total Environ. 2005;336(1-3):81-89. DOI: 10.1016/j.scitotenv.2004.06.002.

[98] Alvarado S, Guédez M, Lué-Merú AP, Nelson G, Alvaro A, Jesús AC, Gyula Z. Arsenic removal from waters by bioremediation with the aquatic plants Water Hyacinth (Eichhornia crassipes) and Lesser Duckweed (Lemna minor). Bioresour Technol. 2008;99(17):8436-8440. DOI: 10.1016/j.biortech.2008.02.051.

[99] Fritioff $\AA$, Greger M. Uptake and distribution of $\mathrm{Zn}, \mathrm{Cu}, \mathrm{Cd}$, and $\mathrm{Pb}$ in an aquatic plant Potamogeton natans. Chemosphere. 2006;63(2):220-227. DOI: 10.1016/j.chemosphere.2005.08.018.

[100] Demirezen D, Aksoy A. Accumulation of heavy metals in Typha angustifolia (L.) and Potamogeton pectinatus (L.) living in Sultan Marsh (Kayseri, Turkey). Chemosphere. 2004; 56(7):685-696. DOI: 10.1016/j.chemosphere.2004.04.011.

[101] Olguín EJ, Sánchez-Galván G. Heavy metal removal in phytofiltration and phytoremediation: the need to differentiate between bioadsorption and bioaccumulation. New Biotechnol. 2012;30(1):3-8. DOI:10.1016/j.nbt.2012.05.020.

[102] Lezcano JM, González F, Ballester A, Blázquez ML, Muñoz JA, García-Balboa C. Sorption and desorption of $\mathrm{Cd}, \mathrm{Cu}$ and $\mathrm{Pb}$ using biomass from an eutrophized habitat in monometallic and bimetallic systems. J Environ Manage. 2011;92: 2666-2674. DOI: 10.1016/j.jenvman.2011.06.004.

\title{
WYKORZYSTANIE ROŚLIN WODNYCH W BIOMONITORINGU I FITOREMEDIACJI WÓD ZANIECZYSZCZONYCH METALAMI CIĘŻKIMI
}

\author{
${ }^{1}$ Samodzielna Katedra Biotechnologii i Biologii Molekularnej, Uniwersytet Opolski
}

\begin{abstract}
Abstrakt: Publikacja jest syntetycznym przeglądem prowadzonych od wielu lat badań, dotyczących możliwości zastosowania roślin wodnych (makrofitów) do oceny zanieczyszczenia wód powierzchniowych oraz możliwości
\end{abstract}


wykorzystania ich biomasy w procesach fitoremediacji. Przedstawiono wyniki badań dotyczących kinetyki i równowag sorpcji metali ciężkich, warunków desorpcji, w celu wielokrotnego wykorzystania biomasy, oraz badań dotyczących wpływu czynników abiotycznych na procesy sorpcji. Omówiono mechanizmy obronne makrofitów, umożliwiające im wegetację w wodach o znacznym zanieczyszczeniu. Zaprezentowane wyniki badań, prowadzonych w wielu krajach świata, wskazują, że makrofity mogą być w przyszłości z powodzeniem wykorzystywane w biomonitoringu środowiska wodnego oraz w fitoremediacji wód i ścieków, przy czym walidacja procedur wymaga dokładniejszego poznania mechanizmów, jakie towarzyszą tym procesom.

Słowa kluczowe: rośliny wodne, metale ciężkie, sorpcja, biomonitoring, fitoremediacja 